\title{
EFFECT OF LINTEL AND LINTEL BAND ON THE GLOBAL PERFORMANCE OF REINFORCED CONCRETE MASONRY IN- FILLED FRAMES
}

\author{
S Bhargavi ${ }^{1}$, Ramancharla Pradeep Kumar ${ }^{2}$ \\ ${ }^{I}$ MS by Research Scholar, Earthquake Engineering Research Centre, International Institute of Information \\ Technology, Hyderabad \\ ${ }^{2}$ Professor, Earthquake Engineering Research Centre, International Institute of Information Technology, Hyderabad
}

\begin{abstract}
Door and window openings are unavoidable components in RC masonry in-filled frames because of functional and ventilation requirements. The presence of openings in RC masonry in-filled frames reduces the lateral stiffness and strength of the wall, which modifies the actual behavior of structure. If these openings are located in the restricted zones like areas within middle two thirds of a wall panel, then the wall needs to be strengthened by providing necessary structural elements such as lintel or lintel bands (i.e., horizontal/vertical bands) around them. Lack of such strengthening techniques may cause the structure to undergo severe damage during the seismic excitations. In this paper, the change in response of RC masonry infilled frames due to the presence of lintels and lintel bands above the openings is studied. For studying the behavior of the frames, static non-linear pushover analysis using Applied Element Method (AEM) based analysis tool has been used.
\end{abstract}

Keywords: Unreinforced brick masonry infill walls, Lintel, Horizontal bands, Vertical bands, Static non-linear pushover analysis, and Applied Element Method and Finite Element method. $* * *$

\section{INTRODUCTION}

Reinforced concrete buildings have gained huge popularity due to various reasons like increase in demand to aesthetic appearance of a building, partition wall requirements, easy applicability in RC frames and low cost. Out of all the kinds of masonry units used for construction, brick masonry is one of the most commonly used materials till date in many parts of the world. Though these infill walls are inevitable, they are considered as non structural elements according to the existing standard codes of practice in many countries. During strong ground motions, the infill brick wall may lose its stability, leading to change in seismic behavior of a building as a whole.

Various studies have been carried out to understand the behavior of infilled frames but the effect of openings (i.e., Door(s) and window(s)) and presence of lintel or lintel bands above the openings are not much studied and are rather neglected in the analysis and design procedures. Lintel is a horizontal beam made up either of stone, wood, steel or reinforced concrete (usually) or pre-tensioned concrete to support the masonry material present above the opening. These are responsible to transfer the load vertically to the supporting walls (Figure 1(a)). Horizontal bands (at sill and lintel) are provided in the masonry structure to hold the walls in place at the time of seismic events (Figure 1(b)). The presence of openings, lintels and lintel bands at the different positions in the wall changes the lateral load transfer mechanism in the structure and may lead to weak infill behavior. The presence of lintels and lintel bands may lead to various effects especially the short column effect and change in the design forces on different structural elements.

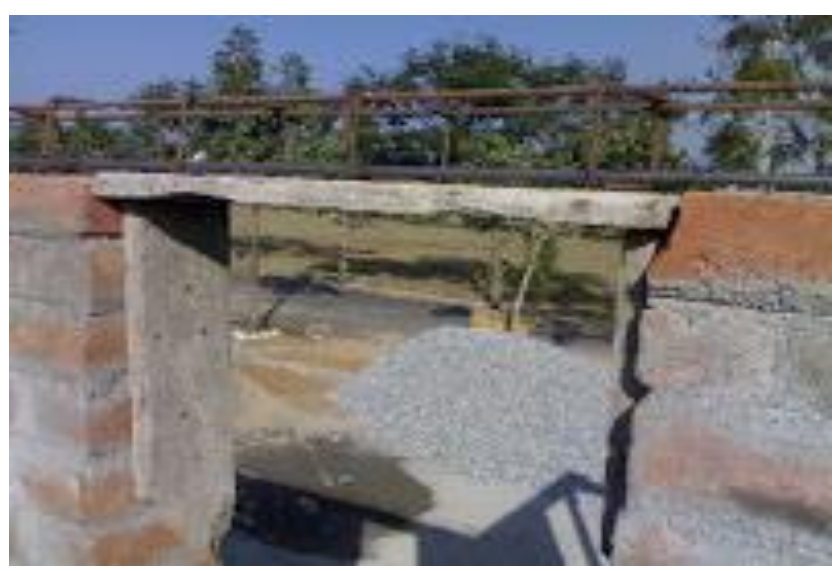

(a)

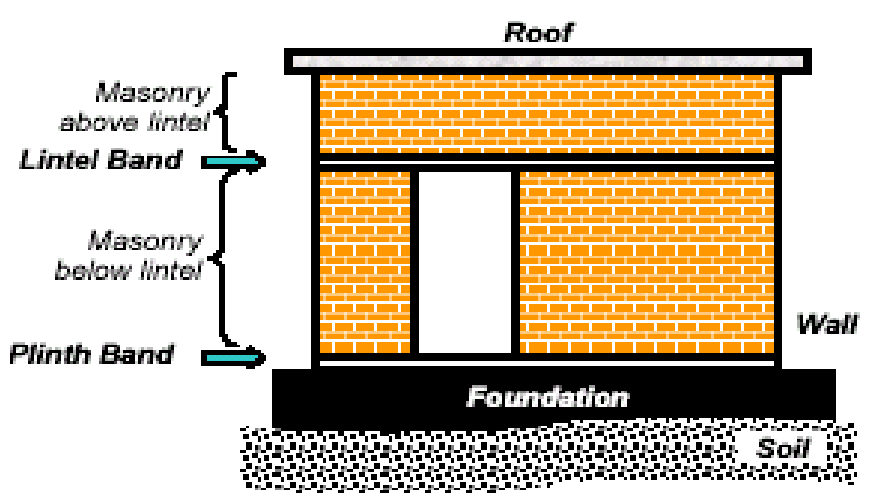

(a) Building with Flat Roof

(b)

Fig 1: (a) Lintel (b) Lintel Band 
From the review of past research work, it has been observed that the presence of infill may avoid the collapse of building by reducing storey drift and increasing lateral load carrying capacity of frame [2]. Experimental study carried out by [12] on RC frame with brick masonry infill has shown that the damage pattern of the structure depends on interaction between the frame and brick infill, and also on the relative strengths of RC frame and the infill panels. The combination of RC frame and brick infill should be in such a way that the energy given by the earthquake is dissipated in the form of brick infill failure, as it can be easily repaired. Presence of strong brick infill may lead to severe damage in RC members, which are the main components of the structure and hence need greater attention in retrofitting them. In the case of RC frames with unreinforced brick masonry in-fills, strengthening of bare frame with brick infill can lead to undesirable huge damage, as the performance of brick infill depends on the relative capacities of beams and columns. On the other hand, in the case of RC frames with reinforced brick masonry in-fills, the plaster thickness and reinforcement meshing in infill can also increase the lateral strength of frame provided that the frame members are designed for the additional forces due to the presence of brick infill [11]. The Indian Standards [9] and [10] provides sizes and details of the bands.

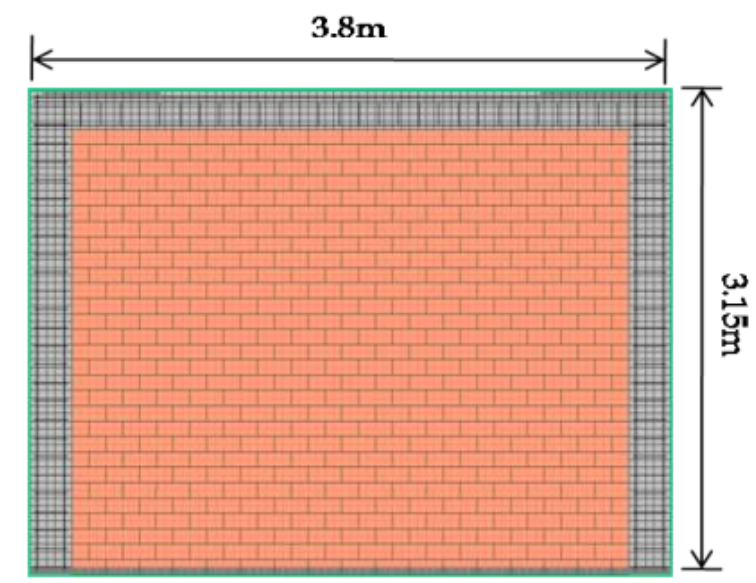

(a)

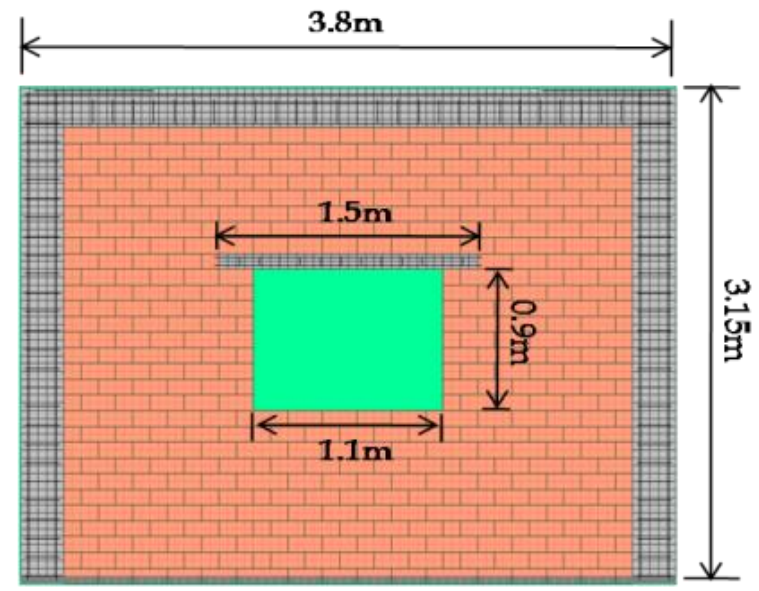

(c)
This paper aims in understanding the seismic behavior of RC masonry infilled frames with lintel and lintel band above the central opening. A Case study is carried out by considering a single bay single storey RC structure with infill wall and a central opening. Pushover analysis is performed on the frame considering four types of infilled frames viz., (a) frame with masonry infill without opening (Figure 2(a)) (b) frame with opening but without lintel and lintel band (Figure 2(b)) (c) frame with lintel above the central opening (Figure 2(c)) and (d) frame with lintel band above opening (Figure 2(d)) and interpretations are derived.

\section{MODELING}

In this study, a single bay single storey non-ductile RC infilled frame is considered and four different types of infill frames were considered (i) RC in-filled frame with no openings (Figure 2(a)) (ii) RC infilled frame with central opening but without lintel or lintel band (Figure 2(b)) (iii) $\mathrm{RC}$ infilled frame with lintel above the opening (Figure 2(c)) and (iv) RC infilled with lintel band above the opening (Figure 2(d)). The material properties and the structural details are given in Table 1 and Table 2 respectively.

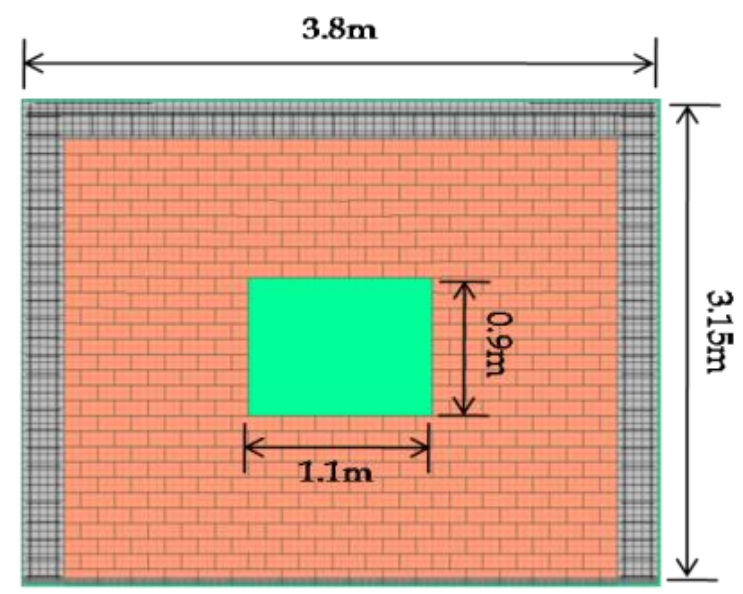

(b)

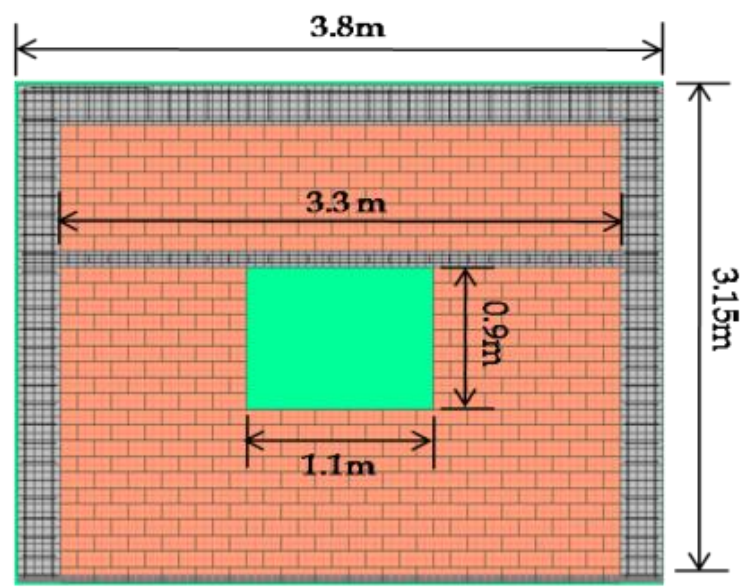

(d)

Fig 2: (a) Frame with masonry infill without opening (b) Frame with opening but without lintel and lintel band (c) Frame with lintel above the central opening and (d) Frame with lintel band above the central opening 
Table 1: Material Properties

\begin{tabular}{|l|l|}
\hline Compressive strength of concrete $\left(\mathrm{f}_{\mathrm{ck}}\right)$ in RC frame & $40 \mathrm{MPa}$ \\
\hline Compressive strength of concrete $\left(\mathrm{f}_{\mathrm{ck}}\right)$ in Lintel and Band & $20 \mathrm{MPa}$ \\
\hline Yield stress in steel $\left(\mathrm{f}_{\mathrm{y}}\right)$ & $415 \mathrm{MPa}$ \\
\hline Poisson's ratio of concrete $(\gamma)$ & 0.2 \\
\hline Compressive strength of brick masonry $\left(\mathrm{f}_{\mathrm{b}}\right)$ & $5 \mathrm{MPa}$ \\
\hline Tensile strength of brick masonry $\left(\mathrm{f}_{\mathrm{t}}\right)$ & $0.5 \mathrm{MPa}$ \\
\hline Compressive strength of mortar $\left(\mathrm{f}_{\mathrm{m}}\right)$ & $3.5 \mathrm{MPa}$ \\
\hline Friction angle in mortar (radians) & 0.75 \\
\hline Cohesion $(c)$ & $0.250 \mathrm{MPa}$ \\
\hline
\end{tabular}

Table 2: Structural Details

\begin{tabular}{|c|c|}
\hline \\
\hline Bay width & $3.8 \mathrm{~m}$ \\
\hline Height & $3.15 \mathrm{~m}$ \\
\hline No of bays & 1 \\
\hline Opening Size & $1.1 \mathrm{~m} \times 0.9 \mathrm{~m}$ \\
\hline Column size & $0.25 \mathrm{~m} \mathrm{x} 0.25 \mathrm{~m}$ \\
\hline Lintel & $0.25 \mathrm{~m} \mathrm{x} 0.1 \mathrm{~m}$ \\
\hline Lintel Length & $1.5 \mathrm{~m}$ \\
\hline Lintel Band & $0.25 \mathrm{~m} \times 0.1 \mathrm{~m}$ \\
\hline Beam size & $0.15 \mathrm{~m} \times 0.25 \mathrm{~m}$ \\
\hline Brick size & $0.2 \mathrm{~m} \times 0.1 \mathrm{~m} \times 0.1 \mathrm{~m}$ \\
\hline
\end{tabular}

According to code provision only those walls with an opening area of less than $10 \%$ of the gross panel area are considered as resisting seismic loads. In this study opening area of $8 \%$ of the gross panel area is considered. The frame is designed in all four models according to IS: $456-2000$. 100mm thick R.C.C. lintels and lintel bands are considered over the $2 \mathrm{~m}$ high brick walls. Two bars of $16 \mathrm{~mm}$ diameter are provided, tied across with steel links of $8 \mathrm{~mm}$ diameter at a spacing of $118 \mathrm{~mm}$ centers as shown in Fig 3.

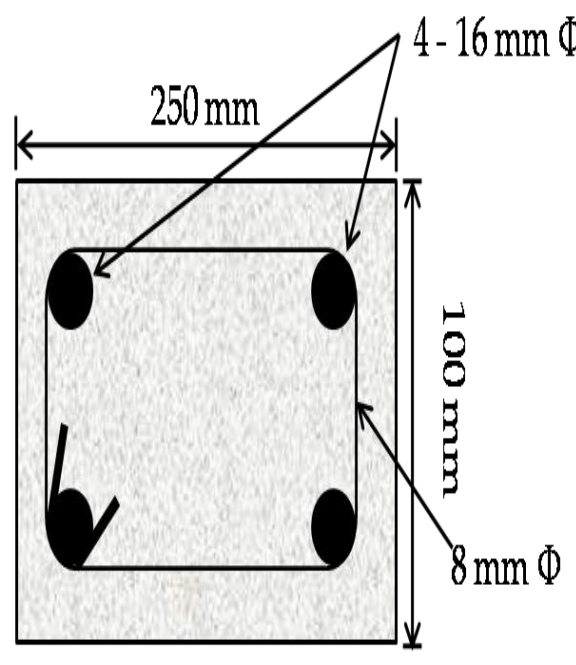

(a)

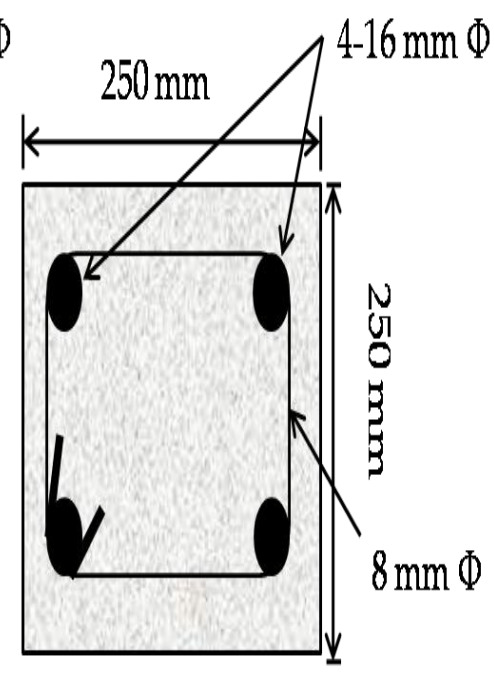

(b)

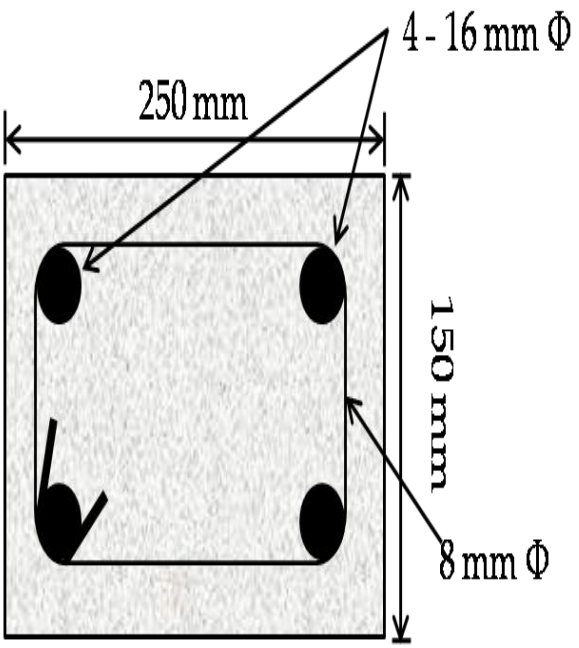

(c)

Fig 3: Reinforcement detailing of (a) Column (b) Beam (c) Lintel and Lintel band 


\section{METHODOLOGY}

Applied Element Method (AEM) was first developed by [14] on RC frames and later continued by [13] for its applicability to brick masonry units. In this methodology, the brick masonry is considered as combination of brick units and mortar units. The interaction between the brick units and the masonry units is established with the help of assumed virtual pair of springs in two directions; one normal and the other shear (Figure 4(a)). Each spring is defined with a failure criteria specified on principal stresses (Figure 4(b)). The forces/stresses in the elements are calculated using the forces/stresses in springs connected between them. The global stiffness matrix generated using connectivity matrix is used to calculate the deformation in three degrees of freedom defined at the centre of each element for a $2 \mathrm{D}$ problem.

Non linear static pushover analysis is used to know the performance and collapse pattern of infill frame. It is an incremental static analysis used to determine the force displacement relationship, or the capacity curve for a structure. The analysis involves applying horizontal loads, in a prescribed pattern, onto the structure incrementally; pushing the structure and plotting the total applied lateral force and associated lateral displacement at each interval, until the structure achieves collapse condition. A plot of the total base shear vs. roof displacement in a structure is obtained by this analysis that would indicate any premature failure or weakness.

Displacement controlled pushover analysis is performed on all the four RC infilled frames which are modeled using AEM. A target displacement of $1.5 \%$ drift is applied on to the structure in positive $\mathrm{x}$ direction and distributed as standard recommendations [3] (Figure 5 to 8).

Displacement controlled pushover analysis is performed on all the four RC infilled frames which are modeled using AEM. A target displacement of $1.5 \%$ drift is applied on to the structure in positive $\mathrm{x}$ direction and distributed as standard recommendations [3] (Figure 5 to 8 ).

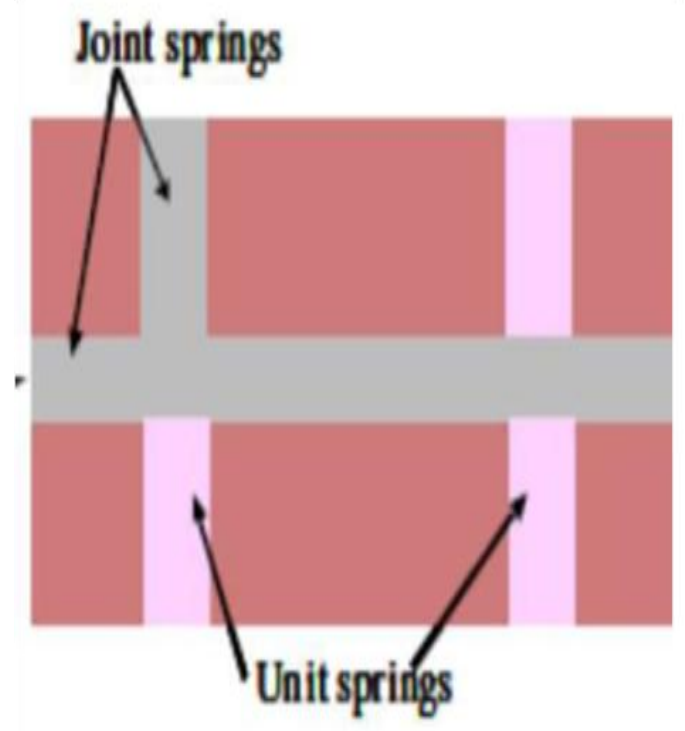

(a)

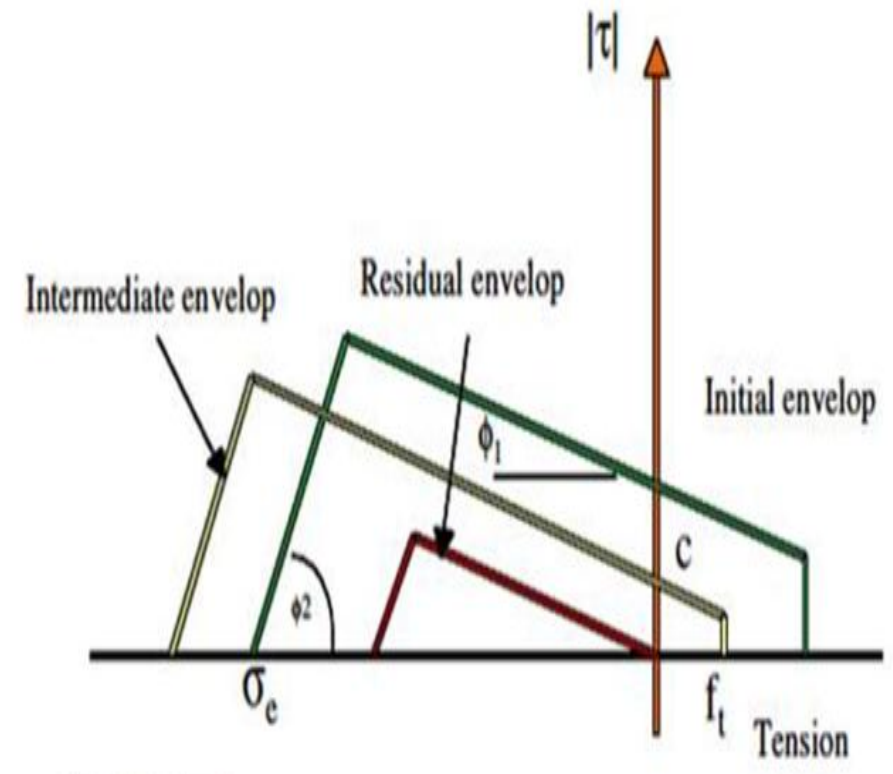

Compression

(b)

Fig 4: (a) Discretization of brick masonry using unit springs and joint/mortar springs (b) Failure criteria for joint/mortar springs

\section{RESULTS AND INTERPRETATION}

The capacity curve characteristics for all the models are presented and are compared mainly in terms of strength degradation and stiffness degradation. The status of the structure at different stages of pushover analysis is shown on the curve indicated with numbers for sequence. The location of the crack is indicated by white colored lines in the brick masonry wall. 


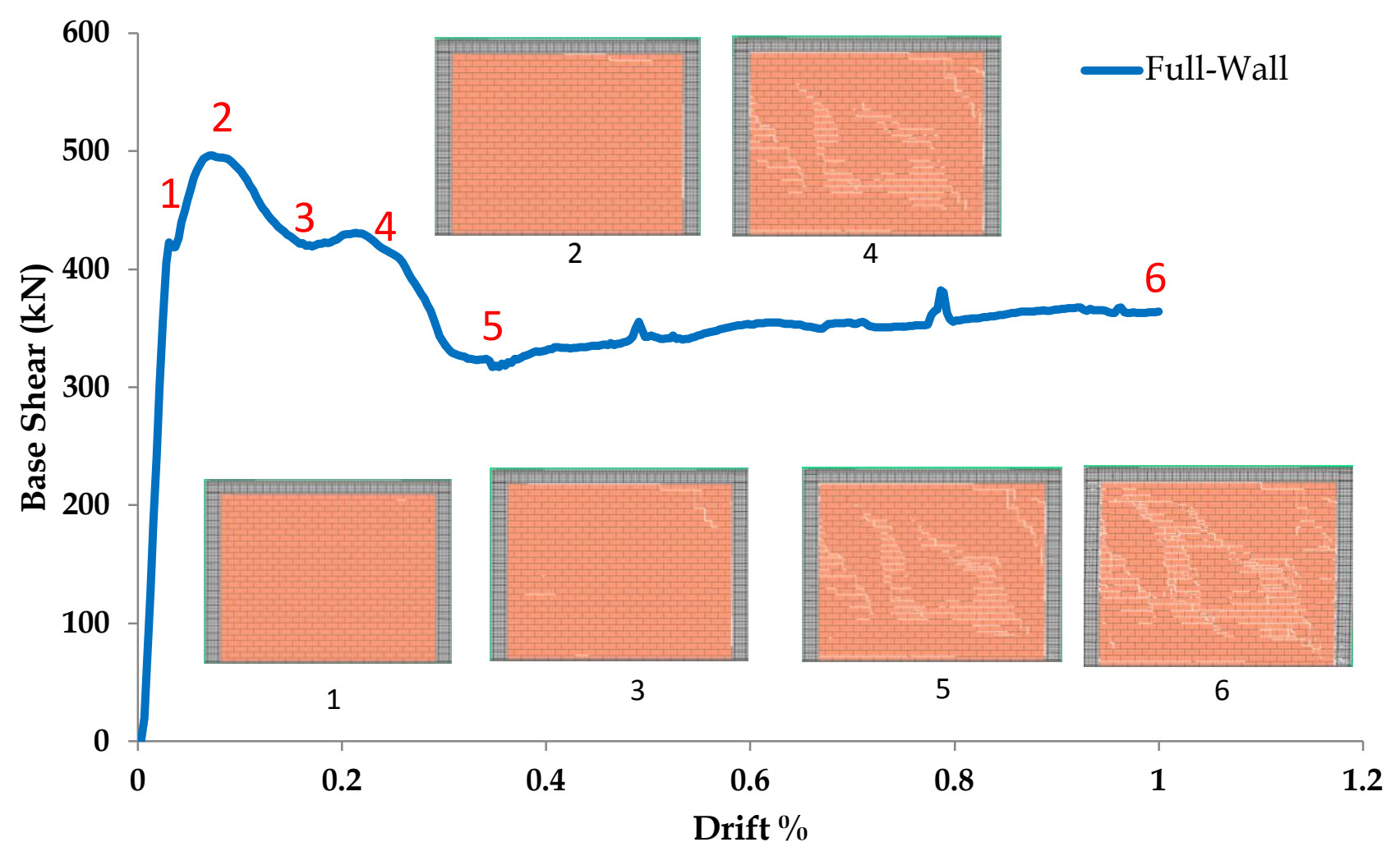

Fig 5: Pushover curve for frame with masonry infill without openings

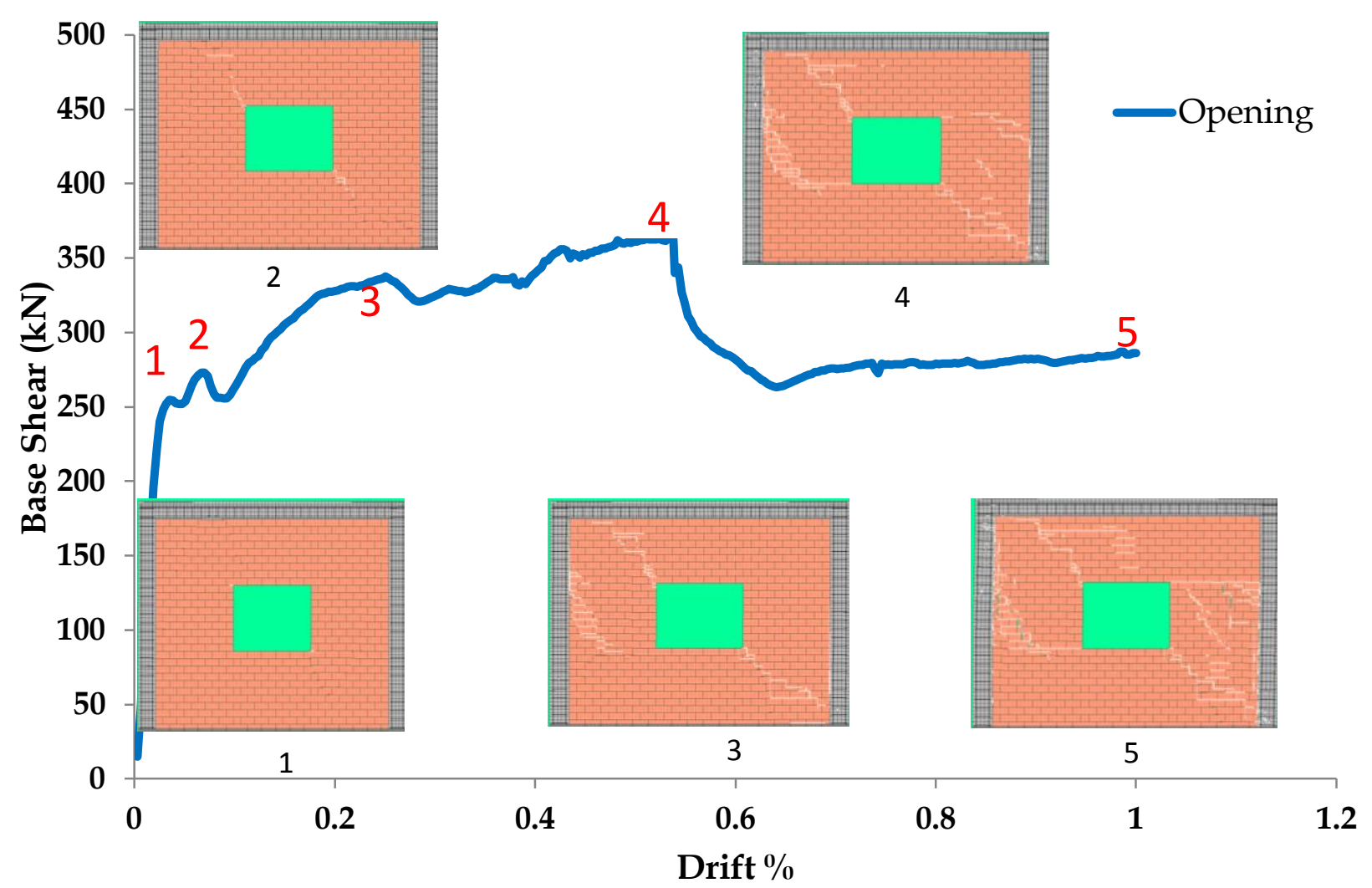

Fig 6: Pushover curve for frame with opening but without lintel and lintel band 


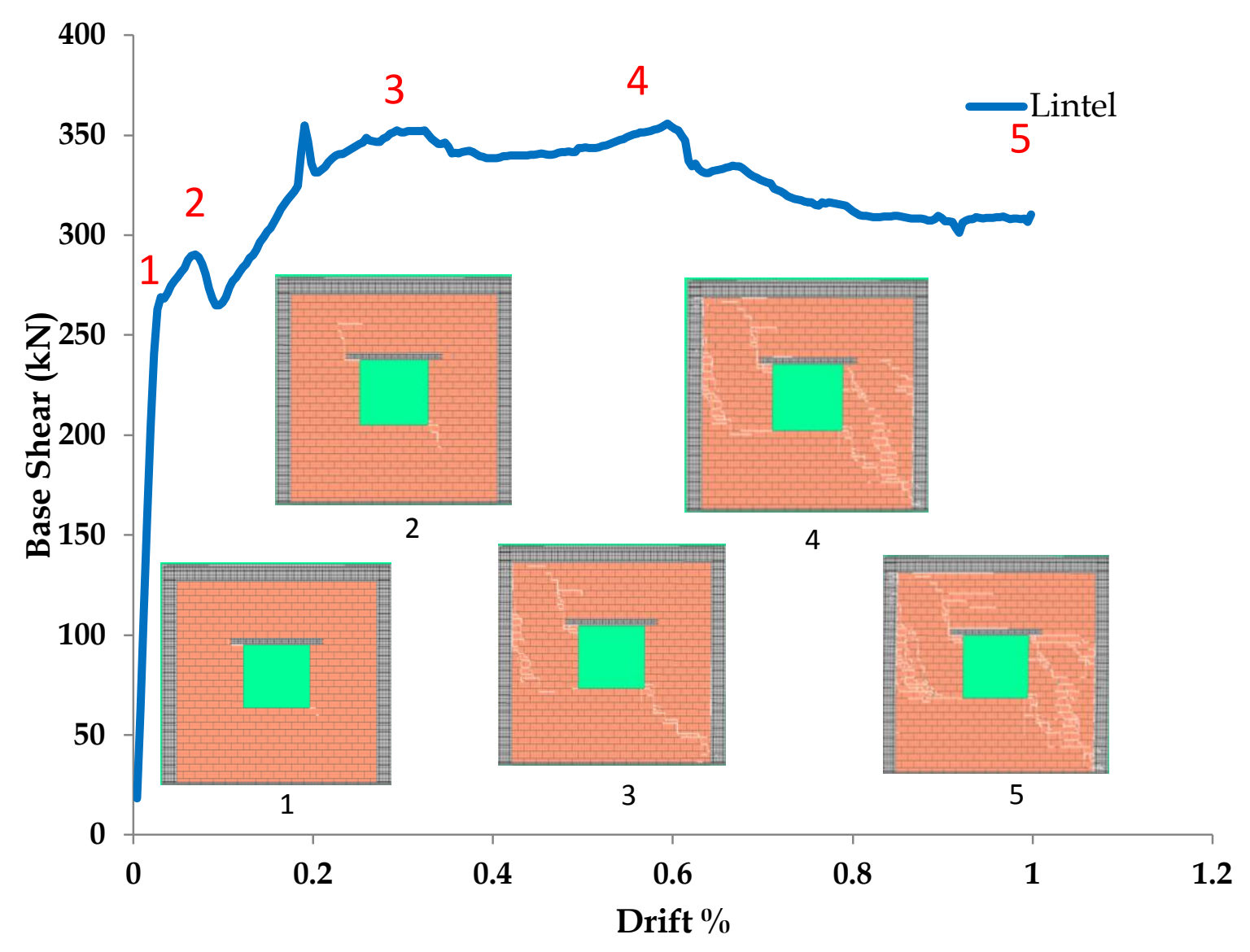

Fig 7: Pushover curve for frame with lintel above the central opening

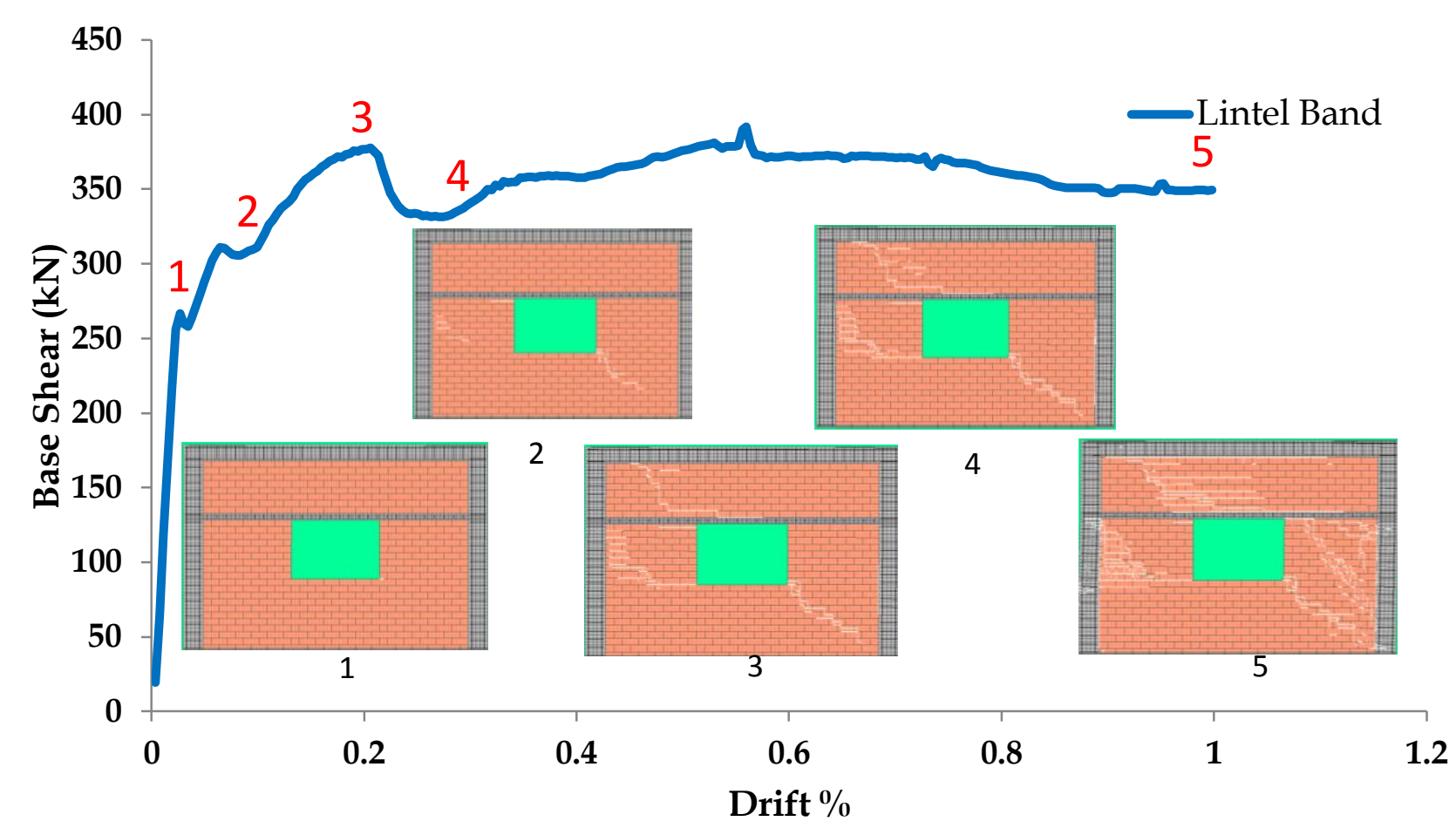

Fig 8: Pushover curve for and frame with lintel band above the central opening 
The initial stiffness and strength of the four frames are quantitatively shown in Table 3. From the table it is observed that the infilled frame with no openings have about $27 \%$ higher Stiffness and 32\% higher strength when compared to the frame with opening, which focus the reduction of stiffness and strength due to the presence of openings. Similarly an increase of 5.5\%, $13 \%$ strength and $2.3 \%, 8 \%$ stiffness is observed for in-filled frame with lintel and lintel band above opening compared to without lintel and lintel band in-filled frame with opening.

Table 4: Comparison of parameters

\begin{tabular}{|l|l|l|l|l|}
\hline S.No & Frame Type & Initial Stiffness(kN/m) & Max Base Shear (kN) & $\begin{array}{l}\text { Displacement @ } \\
\text { Max Base Shear (m) (Drift) }\end{array}$ \\
\hline 1. & Full Wall & $4.05 \times 10^{5}$ & 496.60 & $0.0020(0.06 \%)$ \\
\hline 2. & Opening & $2.97 \times 10^{5}$ & 339.00 & $0.0078(0.25 \%)$ \\
\hline 3. & Lintel & $3.04 \times 10^{5}$ & 358.40 & $0.0102(0.32 \%)$ \\
\hline 4. & Lintel Band & $3.22 \times 10^{5}$ & 387.90 & $0.0065(0.21 \%)$ \\
\hline
\end{tabular}

From the

Table 5, it is observed that the in-filled frame without openings have about $24.5 \%, 12 \%$ increase in base shear at $0.2,0.6$ drift and $5.9 \%$ decrease at 0.4 drift compared to in-filled frame with openings. Similarly an increase of $1.6 \%, 13.5 \%$ at 0.2 drift, $0.2 \%$, $3.9 \%$ at $0.4 \mathrm{drift}$ and $12.4 \%, 17.2 \%$ at $0.6 \mathrm{drift}$ of in-filled frame with lintel and lintel band above opening is observed compared to in-filled frame with opening. In the case of in-filled frame with lintel band above opening an increase in base shear of $12 \%$ at 0.2 drift, $3.7 \%$ at $0.4 \mathrm{drift}$ and $5.5 \%$ at $0.6 \mathrm{drift}$ is observed compared to in-filled frame with lintel above opening.

Table 5: Comparison of Base Shear at different Drift values

\begin{tabular}{|l|l|l|l|l|}
\hline S.No & Frame Type & $\begin{array}{l}\text { Base Shear } \\
\text { @ 0.2\% Drift }\end{array}$ & $\begin{array}{l}\text { Base Shear } \\
\text { @ 0.4 \% Drift }\end{array}$ & $\begin{array}{l}\text { Base Shear } \\
\text { @ 0.6\% Drift }\end{array}$ \\
\hline 1. & Full Wall & 431.33 & 321.20 & 350.44 \\
\hline 2. & Opening & 326.00 & 341.20 & 308.50 \\
\hline 3. & Lintel & 331.25 & 341.90 & 353.20 \\
\hline 4. & Lintel Band & 376.75 & 354.90 & 372.30 \\
\hline
\end{tabular}

Under lateral in-plane loading of an infill frame with opening, high compressive stresses formed across the diagonal of an infill. Transverse to these principal compressive stresses and strains are tensile strains. When the tensile strain exceed the cracking strain of the infill panel material lead to diagonal cracking, as shown in Fig 6 in stage1. These cracks commence at the corners of opening of the infill and run parallel to the compression diagonal as shown in Fig 6 in stage 2. As inter-story drifts increase, the diagonal cracks tend to propagate until they extend from one corner to the diagonally opposite corner in Fig 6 in stage3. This common form of cracking is evident in infill panels with lintel and lintel band above opening as shown in Fig 7 and Fig 8 from stage 1 to stage 3 that have been subjected to lateral loads and occur with bed-joint sliding as shown in Fig 6 to Fig 8 in stage 3 and stage 4. Bed-joint sliding is likely to occur when the bounding frame is strong and flexible. The mortar beds are relatively weak compared to the adjacent brick masonry units, a plane of weakness forms, near the mid-height level of the infill panel. Damage is in the form of minor crushing. Corner compression occurs because of the high stress concentrations at each corner of the compression diagonal. As concrete frames are resistance to applied force is less, corner crushing is more extensive and the damage extended into the concrete frame itself. As inter-story drifts increase, corner crushing becomes more pronounced as shown in Fig 6 to Fig 8 stage5. When this happens, crushing propagates towards the center of the column as shown in figures. Therefore, energy is continuously dissipated via Coulomb friction. The ductility of in-filled frame with lintel band is more compared to the in-filled frame with lintel as shown in figures.

Load vs. displacement curve of RC masonry in-filled frame is shown in Fig 9. From this plot it is clear that the initial response of full wall i.e., infill without opening is higher than the infill with opening. As the drift increases the post peak response of full wall reduces. Due to the brittle behaviour of unreinforced brick masonry compared to reinforced brick masonry among four models response up to peak of in-filled frame with lintel band above opening is better compared to opening in-filled frame and in-filled frame with lintel above opening. As drift increases post peak response of in-filled frame with lintel band is better compared to other three models due to its ductile behaviour. 


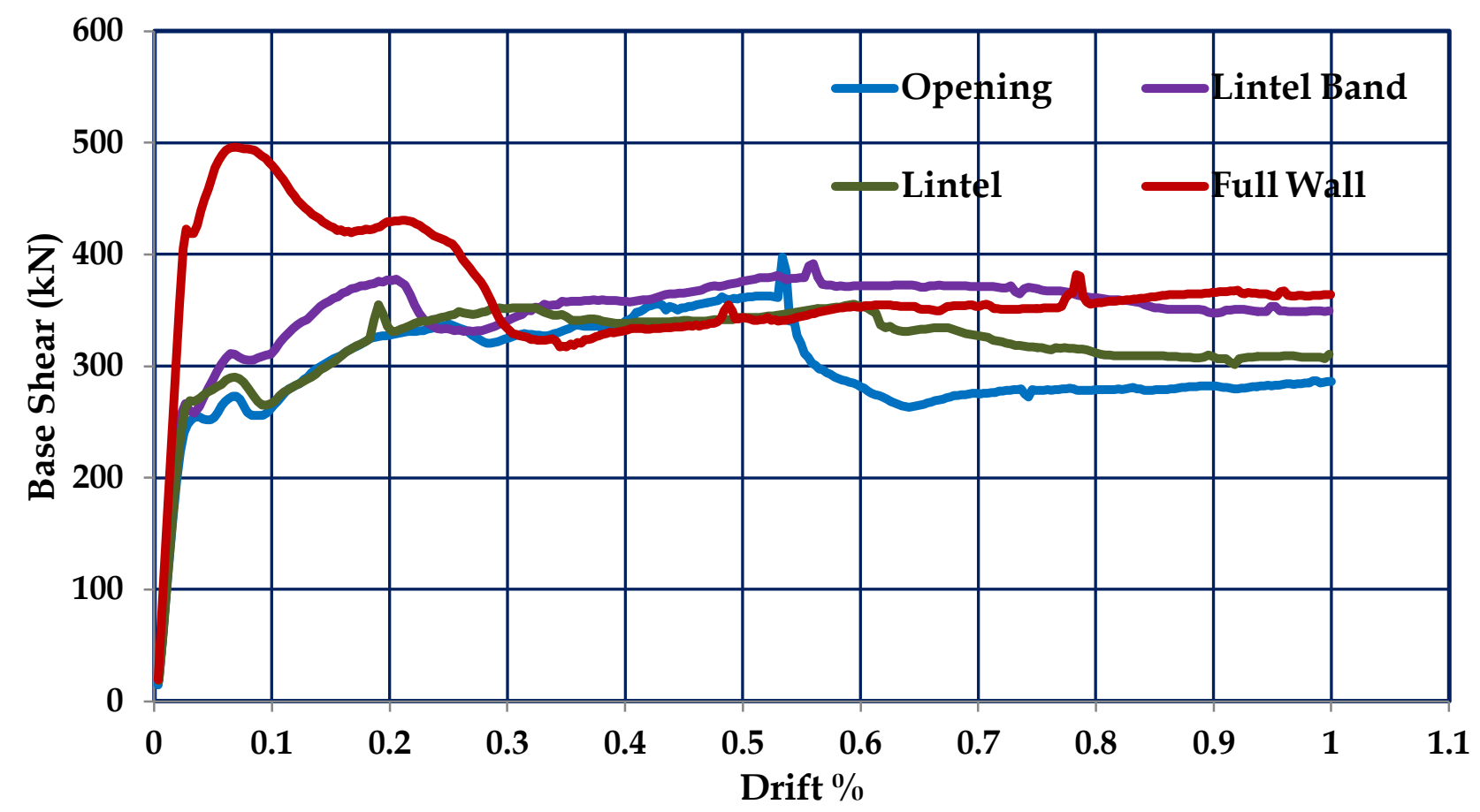

Fig 9: Comparison of pushover curves for the four types of infilled frames

\section{CONCLUSION}

In this paper four brick infilled masonry frames (Full wall, with opening without lintel and lintel band, opening with lintel and opening with lintel band) have been considered. Displacement based pushover is conducted on these frame to understand the effect of lintel and lintel band on overall capacity of the frame. Stiffness, strength and deformation capacities have been studied. It was observed that the infilled frame with no openings have higher stiffness and strength compared to in-filled frame with opening. In-filled frame with opening and without lintel and lintel band losses greater initial stiffness and maximum strength when compared to the in-filled frame with opening and with lintel and lintel band above opening. The performance and strength of in-filled frame with lintel band above opening is higher compared to in-filled frame with lintel. Hence lintel bands increases seismic performance of structure compared to lintels. Therefore, in higher seismic zone areas, providing lintel bands is suggested rather than providing lintels. The conclusions should not be generalized because the numerical experiments were conducted on only one frame.

\section{REFERENCES}

[1] Applied Technology Council (ATC-43 Project), 1999. Evaluation of Earthquake Damaged Concrete and Masonry Wall Buildings-Basic Procedures Manual, prepared for the partnership for Response and Recovery, published by the Federal Emergency Management Agency, FEMA-306, Washington D.C.

[2] Binici, B., Ozcebe, G., and Ozcelik, R. "Analysis and design of FRP composites for seismic retrofit of infill walls in reinforced concrete frames," Compos. Part B-Eng., 38, 575-583, 2007.

[3] FEMA 306 (1998). Evaluation of Earthquake Damaged Concrete and Masonry Wall Buildings Basic Procedures Manual. Chapter 8: Infilled Frames 183-213. Federal Emergency Management Agency. Washington D.C., U.S.A.

[4] Goutam Mondal and Sudhir K. Jain., 2008. "Lateral Stiffness of Masonry Infilled Reinforced Concrete (RC) Frames with Central Opening," Earthquake spectra, Volume 24, No.3, pages 701-723, August (2008)

[5] Hemant B. Kaushik, Durgesh C. Rai and Sudhir K. Jain., 2007. "Stress-Strain Characteristics of Clay Brick Masonry under Uniaxial Compression" Journal of Materials in Civil Engineering ASCE September 2007.

[6] IS 456-1964, 1978, 2000 Indian Standard Code of Practice for Plain and Reinforced Concrete, Indian Standards Institution, New Delhi 110002

[7] IS 1893 (Part 1): 2002 Indian Standard Criteria for Earthquake Resistant Design of Structures, Bureau of Indian Standards, New Delhi 110002.

[8] IAEE, (1986), Guidelines for Earthquake Resistant Non-Engineered Construction, International Association for Earthquake Engineering, Tokyo, available on www.nicee.org

[9] IS 4326, (1993), Indian Standard Code of Practice for Earthquake Resistant Design and Construction of Buildings, Bureau of Indian Standards, New Delhi

[10] IS 13828, (1993), "Indian Standard Guidelines for Improving Earthquake Resistance of Low-strength 
Masonry Buildings," Bureau of Indian Standards, New Delhi.

[11] Korkmaz SZ, Kamanli M, Korkmaz HH, Donduren MS,Cogurcu MT., 2010. "Experimental Study on the Behaviour of Non-ductile In-filled RC frames Strengthened with External Mesh Reinforcement and Plaster composite," Nat. Hazards Earth Syst. Sci., 10: 2305-2316.

[12] Murty, C.V.R., and Nagar, A., 1996. "Effect of Brittle Masonry Infills on Displacement and Ductility Demand of Moment Resisting Frames," Proceedings of Eleventh World Conference on Earthquake Engineering, Acapulco, Mexico.

[13] Pandey, B. H., and Meguro, K., 2004. "Simulation of brick masonry wall behaviour under in plane lateral loading using applied element method," The 13thWorld Conference on Earthquake Engineering, August 1-6, 2004, Vancouver, B.C., Canada.

[14] Tagel-Din Hatem., 1998. "A new efficient method for non linear, large deformation and collapse analysis of structures," A thesis submitted for the fulfillment of award of degree of Doctoral (Ph.D), September, 1998. 